\title{
ANALYSIS OF TEACHERS DIFFICULTY BASED ON 2013 CURRICULUM IMPLEMENTATION IN ELEMENTARY SCHOOL 1 KALIJOYO ALIAN DISTRICT KEBUMEN REGENCY
}

\section{Syifa Khoerunnisa ${ }^{1}$, Maria Ulfah ${ }^{2}$, Purwoko Aji Prasetyo ${ }^{3}$, Kartika Chrysti Suryandari ${ }^{4}$}

Universitas Sebelas Maret ${ }^{1,3,4}$, SD Negeri 1 Kalijoyo $^{2}$

syifa.khoerunnisa317@gmail.com

\section{Article History}

accepted 30/09/2018

approved $12 / 10 / 2018$

published 30/10/2018

\section{Keywords}

Analysis, Difficulties, Implementation, 2013 Curriculum

\begin{abstract}
Many teachers complain about difficulties the implementation of the 2013 curriculum in elementary school, there difficulties about the 2013 curriculum assessment process which considered complicated, the difficulty in applying the scientific approach, and the difficulty of encouraging students to be active in learning. The purpose of this study was to describe the level of difficulty of teachers and knowing what dimensions are difficult for teachers in the 2013 curriculum implementation in elementary school. This research is a descriptive study with a qualitative approach. The results of this study indicate that: (1) The teacher in carrying out the stages of planning and implementing learning based on the 2013 curriculum is categorized as not difficult, meanwhile in conducting learning assessments based on the 2013 curriculum it is categorized as quite difficult; (2) the dimension that is most difficult for teachers in learning based on the 2013 curriculum is the authentic assessment dimension.
\end{abstract}

Social, Humanities, and Education Studies (SHEs): Conference Series https://jurnal.uns.ac.id/shes
p-ISSN 2620-9284 e-ISSN 2620-9292 


\section{PENDAHULUAN}

Bidang pendidikan merupakan komponen yang strategis dalam perkembangan kemajuan teknologi. Dunia pendidikan harus menyiapkan generasi sumber daya manusia yang berkualitas untuk bersaing di era global. Bangsa Indonesia menghadapi berbagai masalah di bidang pendidikan, salah satunya yaitu rendahnya kualitas pendidikan di setiap jenjang. Pemeritah telah berupaya untuk meningkatkan kualitas pendidikan di Indonesia, salah satunya yaitu dengan penyempurnaan kurikulum. Salah satu faktor yang sangat penting dalam menentukan kualitas pendidikan adalah guru. Pada dasarnya kurikulum ditentukan oleh guru (tenaga kependidikan). Kemampuan guru dalam mengajar sangat menetukan tinggi rendahnya kualitas proses dan hasil belajar siswa. Guru akan membawa iklim belajar yang baik apabila guru memiliki kemampuan mengajar yang baik.

Guru memegang peran penting dalam penyusunan dan pelaksanaan kurikulum, dan oleh karenanya guru harus memahami dengan baik masalah kurikulum. Saat ini, dunia pendidikan Indonesia ramai diperbincangkan mengenai penerapan kurikulum 2013. Banyak tanggapan positif dan negatif mengenai perubahan kurikulum dari Kurikulum Tingkat Satuan Pendidikan (KTSP) menjadi Kurikulum 2013. Pembaharuan proses pembelajaran pada kurikulum 2013 terletak pada pembelajaran yang menekankan pada penggunaan pendekatan saintifik.

Dalam bidang kurikulum, guru harus benar-benar bisa memahami kurikulum, mampu mengembangkan kurikulum dan menjadikan kurikulum sebagai pedoman proses belajar mengajarnya. Keberhasilan dari lulusan sangatlah tergantung kepada isi kurikulum dan efektifitas pelaksanaannya. Guru harus menguasai konsep dasar pengelolaan kurikulum, guru juga harus memahami bagaimana mensikapi dan melakukan pengembangan kurikulum baik dalam teori maupun praktek(Sagala, 2009: 18).

Ditinjau dari perubahan yang terjadi bila dibandingkan dengan Kurikulum Tingkat Satuan Pendidikan (KTSP), maka di dalam Kurikulum 2013 lingkup standar nasional pendidikan pada standar kompetensi lulusan, standar isi, standar proses dan standar penilaian menjadi perhatian utama dalam perubahan kurikulum tersebut. Pembelajaran pada Kurikulum 2013 menggunakan tematik integratif, pendekatan scientific, dan juga penilaian auntentik. Tematik integratif merupakan penggabungan dari beberapa mata pelajaran ke dalam satu tema, pendekatan scientific merupakan pendekatan melalui menanya, mencoba, dan menalar, sedangkan penilaian autentik merupakan penilaian yang mengukur semua kompetensi sikap, keterampilan, dan pengetahuan berdasarkan proses dan hasil.

Dalam kurikulum 2013 guru memegang peran yang sangat penting yaitu sebagai fasilitator. Guru bukanlah satu-satunya sumber belajar. Tugas guru dalam kurikulum 2013 adalah mendidik dan membimbing peserta didik agar kegiatan pendidikan terlaksana dengan baik. Guru yang profesional tidak hanya cukup memenuhi persyaratan administratif, melainkan bagaimana guru dapat memberikan pengertian, pemahaman, dan dapat mendorong peserta didik ke arah aktivitas secara individual terhadap ilmu yang diberikannya. Dalam implementasi kurikulum mencakup tiga kegiatan pokok yakni pengembangan program, pelaksanaan pembelajaran, dan evaluasi. Menurut Ningrum dan Sobri (2015: 417) faktor pendukung implementasi Kurikulum 2013 meliputi buku pedoman yang diberikan ketika sosialisasi Kurikulum 2013, arahan dari pengawas, fasilitas sekolah, dan sosialisasi yang diberikan oleh LPMP.

Kesulitan yang dialami guru-guru dalam implementasi kurikulum 2013 adalah beragam. Hal ini disebabkan oleh beberapa faktor, diantaranya yaitu tingkat pemahaman guru yang berbeda-beda dalam mempelajari kurikulum 2013. Banyak guru-guru yang mengeluhkan kesulitan mengenai implementasi kurikulum 2013 diantaranya yaitu proses penilaian kurikulum 2013 yang dianggap rumit, sulitnya 
penerapan pendekatan scientific pada siswa SD, dan sulitnya mendorong peserta didik untuk aktif dalam pembelajaran.

Menurut Mulyasa (2015: 35) kurikulum 2013 sepertinya memiliki kesan yang dipaksakan. Ungkapan tersebut menggambarkan bahwa adanya kesulitan-kesulitan dalam implementasi kurikulum 2013. Hal ini sesuai dengan ungkapan dari guru-guru di SD Negeri 1 Kalijoyo, mereka masih mengalami kendala-kendala dan hambatanhambatan dalam implementasi Kurikulum 2013 di sekolah ini. Oleh karena itu, peneliti tertarik untuk menganalisis kesulitan guru SD Negeri 1 Kalijoyo Kecamatan Alian Kabupaten Kebume dalam impelementasi kurikulum 2013. Tujuan dari penelitian ini adalah untuk mendeskripsikan tingkat kesulitan guru dalam implementasi kurikulum 2013 dan mengetahui dimensi apa yang paling menyulitkan guru dalam implementasi kurikulum 2013 di SD.

\section{METODE}

Penelitian ini tergolong kedalam penelitian dengan menggunakan pendekatan kualitatif, karena peneliti mendeskripsikan suatu fenomena sesuai dengan keadaan yang sebenarnya dialami oleh subyek penelitian dan menyajikan data tersebut dalam bentuk kata-kata dan bahasa. Jenis penelitian ini adalah studi kasus deskriptif, peneliti dalam penelitian ini bentindak sebagai instrumen kunci yang langsung terjun ke lapangan karena peneliti sebagai instrument utama dan bisa mengambil dan mengumpulkan data secara langsung dari responden dengan tujuan memberikan gambaran tentang implementasi kurikulum 2013.

Penelitian ini dilaksanakan di SD Negeri 1 Kalijoyo Kecamatan Alian Kabupaten Kebumen. Instrumen yang digunakan dalam penelitian ini berupa lembar observasi dan pedoman focus grup discusion serta catatan yang digunakan untuk merekam responden dalam mengembangkan pembelajaran. Data pada penelitian ini diolah dengan menggunakan analisis deskriptif.

Penelitian deskriptif pada umumnya dilakukan dengan tujuan utama, yaitu menggambarkan secara sistematis fakta dan karakteristik objek atau subjek yang diteliti secara tepat. Objek yang dideskripsikan dalam penelitian ini adalah tingkat kesulitan guru SD Negeri 1 Kalijoyo Kecamatan Alian Kabupaten Kebumen dalam implementasi kurikulum 2013. Subjek penelitian ini adalah guru di SD Negeri 1 Kalijoyo yang baru saja mengimplementasikan kurikulum 2013 pada tahun ajaran 2018/2019.

\section{HASIL DAN PEMBAHASAN}

Penelitian ini dimaksudkan untuk mengetahui gambaran mengenai tingkat kesulitan guru dalam pembelajaran di Sekolah Dasar berdasarkan Kurikulum 2013. Tingkat kesulitan tersebut diukur dengan lembar observasi yang berjumlah 31 butir pertanyaan dengan rentang skor $1-4$.

\section{Aspek Perencanaan Pembelajaran Menggunakan Pendekatan Saintifik pada Kurikulum 2013 di SD Negeri 1 Kalijoyo Kecamatan Alian Kabupaten Kebumen}

Menurut Sani (2014: 284) Aspek perencanaan pembelajaran, digunakan sebagai pedoman dalam melaksanakan kegiatan pembelajaran, pada aspek perencanaan pembelajaran terdapat komponen penting yang tediri dari, identitas sekolah, identitas mata pelajaran atau tema/sub tema, kelas/semester, materi pokok, alokasi waktu, kompetensi inti, kompetensi dasar, indikator pembelajaran, tujuan pembelajaran, materi pembelajaran, metode pembelajaran, media dan sumber pembelajaran, langkah-langkah pembelajaran, dan penilaian atau evaluasi

\section{Guru Kelas I}

Guru kelas I dalam pembuatan perencanaan pembelajaran merasa sangat kesulitan, apalagi dalam hal menyediakan media, alat, dan bahan yang mendukung proses pembelajaran sesuai kurikulum 2013 serta dalam pembuatan instrumen pembelajaran dengan teknik penilaian otentik guru kelas I SD Negeri 1 Kalijaya 
sangatlah merasa kesulitan. Guru terkadang tidak membuat RPP untuk pembelajaran hari tersebut dengan alasan keterbatasan waktu, rumitnya pembuatan RPP kurikulum 2013 dengan menggunakan pendekatan saintifik. Hal ini bertolak belakang dengan pendapat Sani (2014:261) yang menyatakan bahwa pola pikir dalam proses pembelajaran harus dituangkan dalam rencana pelaksanaan pembelajaran dengan memperhatikan prinsip-prinsip yang ditentukan oleh pemerintah dalam penyusunan RPP.

\section{Guru Kelas IV}

Guru kelas IV dalam pembuatan perencanaan pembelajaran merasa cukup kesulitan, dalam beberapa hal diantaranya yaitu menentukan model pembelajaran yang sesuai dengan kurikulum 2013 dan menyediakan media, alat, dan bahan yang mendukung proses pembelajaran sesuai kurikulum 2013. Untuk perangkat perencanaan pembelajaran pada guru kelas IV SDN 1 Kalijoyo, sudah menunjukkan tentang kelengkapan beberapa komponen seperti identitas, kompetensi inti, kompetensi dasar, indikator pembelajaran, tujuan pembelajaran, materi pokok, pendekatan menggunakan saintifik dan untuk metode pembelajaran menggunakan tanya jawab dan penugasan. Hal ini sesuai dengan kelengkapan komponen RPP dalam Panduan Teknis Kemendikbud 2013 bahwa komponen RPP yang dikehendaki terdiri dari "identitas (nama sekolah, kelas, semester, tema, subtema, dan alokasi waktu ), KI, KD, indikator, tujuan, materi, metode, langkah-langkah pembelajaran, serta penilaian" (Kemendikbud, $2013: 19)$.

\section{Aspek Pelaksanaan Pembelajaran Menggunakan Pendekatan Saintifik pada Kurikulum 2013 di SD Negeri 1 Kalijoyo Kecamatan Alian Kabupaten Kebumen Guru Kelas I}

Kesulitan yang dialami guru Kelas I SD Negeri 1 Kalijoyo dalam melaksanakan pembelajaran menggunakan pendekatan saintifik merasa sangat kesulitan dalam melaksanakan tahap kegiatan "mencipta" pada saat pembelajaran. Pelaksanaan pendekatan saintifik dalam pembelajaran sudah berpusat pada siswa namun masih belum terhindar dari verbalisme, dimana guru kelas I di SDN Kalijoyo masih mendominasi dengan kegiatan ceramah dalam pembelajarannya. Langkah-langkah pembelajaran saintifik sudah diterapkan pada beberapa kegiatan dalam satu pembelajaran namun belum dapat dilakukan secara efektif dan efisien.

Selain itu juga guru mengalami kesulitan dalam hal mengajak siswa untuk aktif dalam kegiatan menanya karena hampir seluruh siswa kelas I di SD Negeri 1 Kalijoyo tersebut termasuk siswa yang sangat pasif. Guru juga merasa kesulitan mengorganisasi siswa dalam kegiatan mencoba karena siswa rata-rata kurang fokus dan bermain sendiri dalam kegiatan mencoba dan mengamati. Dalam kegiatan menalar hanya sebagian siswa yang dapat melaksanakannya karena guru sendiri kurang memahami esensi kegiatan menalar sehingga kegiatan ini jarang dilakukan. Dalam kegiatan mengkomunikasikan guru menghadapi kesulitan dimana siswa kurang aktif dan tidak mau untuk diajak mempresentasikan hasil kerjanya.

\section{Guru Kelas IV}

Kesulitan yang dialami guru kelas IV di SD Negeri 1 Kalijoyo dalam melaksanakan pembelajaran menggunakan pendekatan saintifik sama dengan kesulitan yang dialami guru kelas I yaitu merasa sangat kesulitan dalam melaksanakan tahap kegiatan "mencipta" pada saat pembelajaran. Namun dalam pembelajaran ratarata sudah melaksanakan langkah-langkah penedekatan saintifik meskipun belum dapat berjalan optimal. Guru selalu berupaya untuk melakukan diskusi dan berbagi informasi dengan teman sejawat yang berada dalam satu tingkatan kelas yang sama maupun berbeda. Guru melakukan pertemuan pada hari sabtu untuk mendiskusikan dan mencari pemecahan masalah bersama terhadap kendala yang sedang dihadapi dikelas IV. 
Aspek Penilaian Otentik pada Kurikulum 2013 di SD Negeri 1 Kalijoyo Kecamatan Alian Kabupaten Kebumen

Guru Kelas I

Dalam pelaksanaan penilaian otentik pada kurikulum 2013 guru kelas I di SD Negeri 1 Kalijoyo merasa belum memahami konsep dasar dari penilaian otentik, sehingga guru jarang melaksanakan kegiatan penilaian otentik pada pembelajaran kurikulum 2013. Guru juga merasa kesulitan dalam memahami Standar Kompetensi Lulusan (SKL) pada tiap mata pelajaran ranah sikap, keterampilan, dan pengetahuan dalam kurikulum 2013.

\section{Guru Kelas IV}

Kesulitan yang dialami guru kelas IV di SD Negeri 1 Kalijoyo dalam melaksanakan penilaian otentik sama dengan kesulitan yang dialami guru kelas I yaitu guru merasa belum memahami konsep dasar dari penilaian otentik, sehingga guru jarang melaksanakan kegiatan penilaian otentik pada pembelajaran kurikulum 2013. Sedangkan guru kelas IV SD Negeri 1 Kalijoyo cukup merasa kesulitan dalam memahami Standar Kompetensi Lulusan (SKL) pada tiap mata pelajaran ranah sikap, keterampilan, dan pengetahuan dalam kurikulum 2013.

Tabel 1. Rata-rata Skor Observasi Analisis Kesulitan Guru dalam Implementasi Kurikulum 2013 di SD Negeri 1 Kalijoyo

\begin{tabular}{lcc}
\multicolumn{1}{c}{ Aspek } & \multicolumn{2}{c}{ Skor Rata-rata } \\
& Kelas I & Kelas IV \\
\hline Perencanaan Pembelajaran & 2,18 & 1,73 \\
Pelaksanaan Pembelajaran & 2 & 1,45 \\
Penilaian Otentik & 3.33 & 2,22 \\
\hline
\end{tabular}

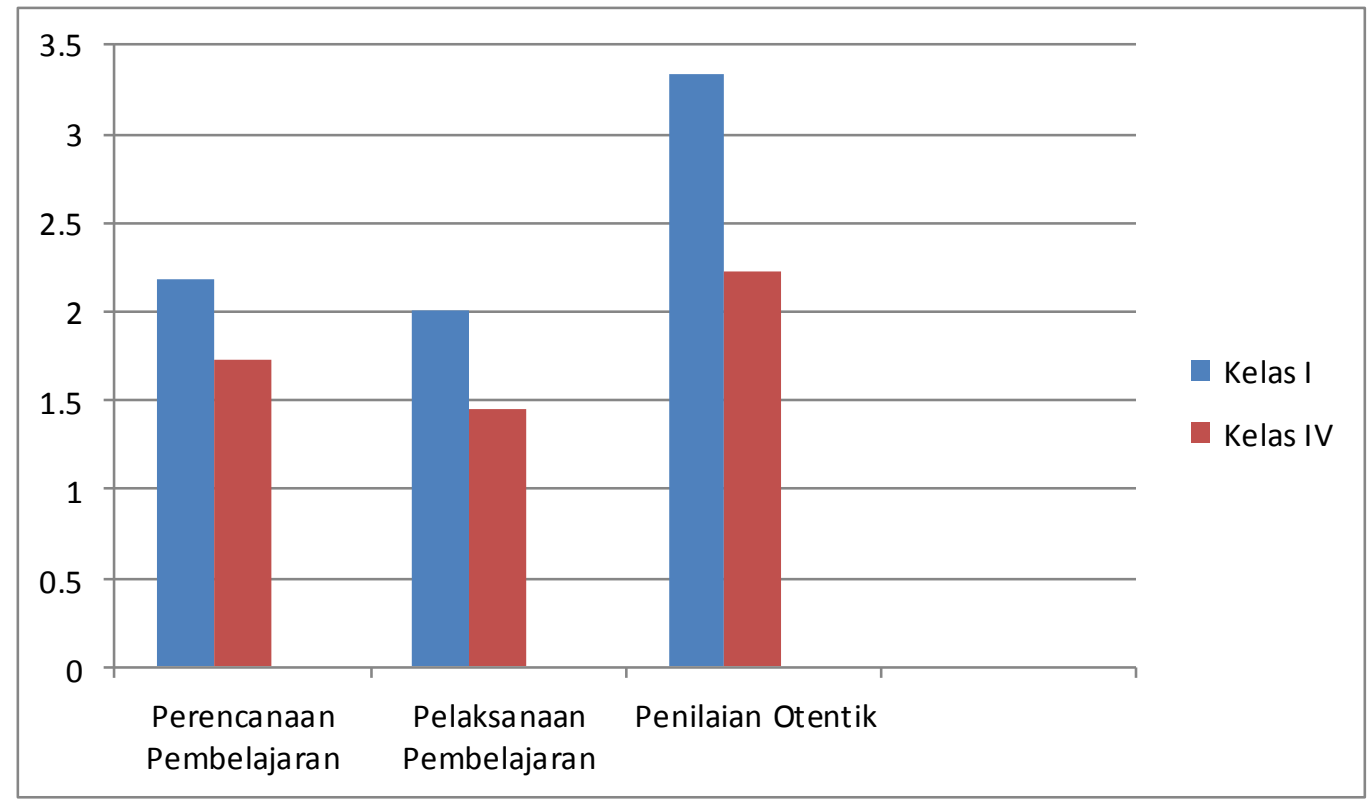

Gambar 1. Hasil Observasi Analisis Kesulitan Guru dalam Implementasi Kurikulum 2013 di SD Negeri 1 Kalijoyo 


\section{SIMPULAN}

Berdasarkan hasil penelitian yang diperoleh melalui analisis dan pembahasan tentang "Analisis Kesulitan Guru dalam Implementasi Kurikulum 2013 di SD Negeri 1 Kalijoyo Kecamatan Alian Kabupaten Kebumen" adalah sebagai berikut:

1. Guru di SD Negeri 1 Kalijoyo dalam melakukan tahapan perencanaan dan pelaksanaan pembelajaran berdasarkan kurikulum 2013 masuk dalam kategori tidak sulit, sedangkan dalam melakukan penilaian pembelajaran berdasarkan kurikulum 2013 masuk dalam kategori cukup sulit.

2. Dimensi yang paling menyulitkan guru di SD Negeri 1 Kalijoyo dalam pembelajaran berdasarkan kurikulum 2013 adalah dimensi penilaian otentik.

\section{DAFTAR PUSTAKA}

Hamalik, O. (2013). Proses Belajar mengajar. Jakarta: Bumi Aksara.

Kemendikbud. 2013. Panduan Teknis Pembelajaran Tematik Terpadu dengan Pendekatan Saintifik di Sekolah Dasar. Jakarta : Kemendikbud

Mulyasa. (2015). Pengembangan dan Implementasi Kurikulum 2013. Bandung: PT. Remaja Rosdakarya

Ningrum, Elwiyen Sulistiya \& Sobri, Ahmad Yusuf. (2015). Implementasi Kurikulum 2013 di Sekolah Dasar. Manajemen Pendidikan. 24 (5), 416 - 423.

Sagala, S. (2009). Kemampuan Profesional Guru dan Tenaga Kependidikan. Bandung: Alfabeta.

Sani. (2014). Pembelajaran Saintifik untuk Implementasi Kurikulum 2013. Jakarta : Bumi Aksara. 